\title{
STRATEGI KEPALA SEKOLAH DALAM MENINGKATKAN KINERJA GURU
}

\author{
Marianita $^{1}$, Army Yuneti ${ }^{2}$ \\ STKIP PGRI Lubuklinggau ${ }^{1,2}$ \\ Marianita2019@gmail.com ${ }^{1}$
}

\begin{abstract}
ABSTRAK
Tujuan penelitian untuk meningkatkan kinerja guru di SMA Negeri 4 Lubuklinggau, bagaimana prinsip peningkatan permormance guru. Metode penelitian yang digunakan adalah studi deskriptif, observasi dan dokumentasi, dan penelitian ini juga menggunakan jenis prosedur untuk mengembangkan bahan. Hasil penelitian kepala sekolah telah menerapkan strategi kepemimpinanya dengan baik, dengan cara memahami kondisi dan keadaan guru, kreatif dalam menerapkan gaya kepemimpinan, memiliki kiat-kiat dan memiliki motivasi yang tinggi untuk meningkatkan kinerja guru. Simpulan dari penelitian ini adalah penelitian ini digunakan untuk meningkatkan kinerja siswa SMA, dan memiliki motivasi tinggi untuk meningkatkan kinerja guru.
\end{abstract}

Kata Kunci: Strategi Prinsip, Meningkatkan Kinerja Guru

\section{ABSTRACT}

The purpose of the study is to improve teacher performance in SMA Negeri 4 Lubuklinggau, how is the principle of increasing teacher permormance. The research method used is descriptive study, observation and documentation, and this study also uses a type of procedure to develop materials. The results of research on principals have implemented leadership strategies well, by discussing the conditions and conditions of teachers, creativity in applying leadership styles, having tips and having motivations that improve to improve teacher performance. The conclusion of this study is that this study is used to improve the performance of high school students, and have high motivation to improve teacher performance.

Keywords: Principle Strategy, Improve Teacher Performance

\section{PENDAHULUAN}

Peningkatan mutu pendidikan ditentukan oleh kesiapan sumber daya manusia yang terlibat dalam proses pendidikan. Guru merupakan salah satu faktor penentu tinggi rendahnya mutu hasil pendidikan mempunyai posisi strategis maka setiap usaha peningkatan mutu pendidikan perlu memberikan perhatian besar kepada peningkatan guru baik dalam segi jumlah maupun mutunya. Guru adalah figur manusia sumber yang menempati posisi dan memegang peran penting dalam pendidikan. Ketika semua orang mempersoalkan masalah dunia pendidikan figur 
guru mesti terlibat dalam agenda pembicaraan terutama yang menyangkut persoalan pendidikan formal di sekolah.

Pendidik atau guru merupakan tenaga profesional yang bertugas merencanakan dan melaksanakan proses pembelajaran, menilai hasil pembelajaran, melakukan pembimbingan dan pelatihan, serta melakukan penelitian dan pengabdian kepada masyarakat, terutama bagi pendidik pada perguruan tinggi. Hal tersebut tidak dapat disangkal karena lembaga pendidikan formal adalah dunia kehidupan guru.sebagai besar waktu guru ada di sekolah, sisanya ada di rumah dan di masyarakat (Djamarah, 2000).

Guru merupakan ujung tombak pendidikan sebab secara langsung berupaya mempengaruhi, membina dan mengembangkan peserta didik, sebagai ujung tombak, guru dituntut untuk memiliki kemampuan dasar yang diperlukan sebagai pendidik, pembimbing dan pengajar dan kemampuan tersebut tercermin pada kompetensi guru. Berkualitas tidaknya proses pendidikan sangat tergantung pada kreativitas dan inovasi yang dimiliki guru. Gunawan (1996) mengemukakan bahwa Guru merupakan perencana, pelaksana sekaligus sebagai evaluator pembelajaran di kelas, maka peserta didik merupakan subjek yang terlibat langsung dalam proses untuk mencapai tujuan pendidikan.

Kepala sekolah bertanggungjawab terhadap sukses atau tidaknya sekolah yang dipimpin, kepala sekolah merupakan faktor kunci, karena kepala sekolah memegang peranan penting dalam pengelolaan sekolah. Reza (2008) menjelaskan bahwa pembinaan terhadap guru merupaka salah satu tugas dari kepala sekolah sebagai pemimpin sekolah, namun dalam pembinaan terhadap guru masih sangat memperhatinkan, program dan kegiatan pembinaan serta pengembangan kompetensi guru, khususnya komponen-komponen profesional.

Berdasarkan kondisi dilapangan di SMA Negeri 4 Kota Lubuklinggau pembinaan terhadap guru masih terbatas pada rapat pembinaan yang dilakukan secara umum kepada semua guru dalam periode tertentu, sehingga belum terarah kepada masing-masing guru bidang studi. Melihat kondisi ini, maka diperlukan strategi kepala sekolah dalam melakukan pembinaan terhadap guru, sebab guru memiliki karakteristik, keinginan dan motivasi yang berbeda-beda dalam melakukan tugas pokok dan fungsinya sebagai tenaga pendidik, maka dari itu kepala sekolah hendaknya menerapkan strategi yang bervariatif dalam memberikan pembinaan kepada guru. Diharapkan dengan pembinaan yang dilakukan oleh kepala sekolah dapat meningkatkan kinerja guru dalam kegiatan belajar dan mengajar di sekolah.

\section{METODE PENELITIAN}

Dalam penelitian ini penulis memilih pendekatan deskriftif kualitatif, yakni suatu proses penelitian yang menghasilkan data deskriftif baik berupa tulisan atau ungkapan yang diperoleh langsung dari lapangan atau wilayah penelitian tentang strategi kepala sekolah dalam meningkatkan kinerja guru di SMA Negeri 4 Kota 
Lubuklinggau. Dalam penelitian kualitatif peneliti adalah sebagai instrumen kunci, sumber data dilakukan secara purposive dan snowwball, teknik pengumpulan dengan triangulasi (gabungan), analisa data bersifat induktif atau kualitatif dan hasil penelitian kualitatif lebih menekankan makna dari pada generalisasi.

Subyek dalam penelitian ini adalah segenap orang yang dipandang oleh peneliti dapat memberikan data tentang strategi kepala sekolah dalam meningkatkan kinerja guru di SMA Negeri 4 Kota Lubuklinggau. Subyek penelitian terdiri dari kepala sekolah, dewan guru dan staf SMA Negeri 4 Kota Lubuklinggau.

Pada penelitian ini menggunakan metode pengumpulan data observasi, wawancara dan dokumentasi.Teknik dokumentasi dan observasi hanya digunakan sebagai pelengkap data.Data yang diambil dalam penelitian ini berupa data yang berhubungan dengan strategi kepala sekolah dalam meningkatkan kinerja guru di SMA Negeri 4 Kota Lubuklinggau.

Disamping itu juga dilakukan triangulasi. Trianggulasi yaitu pemeriksaan silang dari berbagai sumber yang digunakan. Triangulasi yang banyak digunakan adalah triangulasi dengan sumber yaitu membandingkan dan mengecek balik derajat kepercayaan suatu informasi yang diperoleh melalui waktu dan alat yang berbeda dalam penelitian. Lebih jelasnya trianggulasi dilakukan dengan jalan 1) membandingkan data hasil wawancara dengan hasil pengamatan, 2) membandingkan apa yang dikatakan orang di depan umum dengan apa yang dikatakan secara pribadi, 3) membandingkan apa yang dikatakan orang tentang tentang situasi penelitian dengan apa yang dikatakan sepanjang waktu, 4) membandingkan keadaan dan perspektif seseorang dengan berbagai pandangan orang dari berbagai latar belakang, 5) membandingkan hasil wawancara dengan isi dokumen yang berkaitan.Trianggulasi dilakukan bersamaan dengan kegiatan pengamatan dilapangan, sehingga peneliti bisa melakukan pencatatan data secara lengkap. Dengan demikian maka data hasil penelitian ini layak untuk dimanfaatkan.

\section{HASIL DAN PEMBAHASAN}

\section{Pemahaman Kepala Sekolah dalam Meningkatkan Kinerja Guru}

Kepala sekolah merupakan pemimpin yang tertinggi di sekolah, maju mundurnya sekolah tergantung kepemimpinan kepala sekolah. Kepala sekolah harus cepat tanggap terhadap persoalan sekolah mulai dari persoalan siswa, guru, sarana dan prasarana, kurikulum dan sebagainya. Disamping tanggap terhadap persoalan sekolah, kepala sekolah juga harus benar-benar dapat memahami kekuatan dan kelemahaman sekolah, kemudian peluang dan tantangan sekolah kedepannya. Sebelum memahami persoalan sekolah, kepala sekolah harus mengetahui terlebih dahulu dengan jalan mengidentifikasi persoalan sekolah, sehingga kepala sekolah dapat memahami dan mendapatkan solusi dalam 
penyelesainnya. Hasil wawancara dengan kepala sekolah SMA Negeri 4 Kota Lubuklinggau adalah sebagai berikut:

"Sebelum memahami persoalan sekolah saya terlebih dahulu mengetahui apaapa yang menjadi persoalan sekolah dengan jalan mengidentifikasi kebutuhan sekolah kedepannya, sehingga saya dapat membuat skala prioritas yang mana harus diselesaikan secepat mungkin, sehingga setahap demi setahap persoalan sekolah dapat terselesaikan dengan baik"

Peningkatan kinerja guru merupakan hal yang tidak dapat ditawarkan lagi dalam penyelesainnya, sebab guru merupakan ujung tombak dari keberhasilan siswa, guru perlu dimotivasi dan diperhatikan oleh kepala sekolah selaku pemimpin tertinggi di sekolah, kepala sekolah harus dapat menciptakan iklim kerja yang baik di sekolah, agar guru dalam menjalankan tugas pokok dan fungsinya dapat berjalan sesuai dengan harapan. Tingkat pengetahuan kepala sangat diperlukan dalam menciptkan iklim sekolah yang baik sehingga kinerja guru dalam menjalankan tugas pokok dan fungsinya dapat berjaan sesuai dengan yang diharapkan.

\section{Kreativitas Kepala Sekolah dalam Meningkatkan Kinerja Guru}

Dalam meningkatkan kinerja guru kepala sekolah harus memiliki ide yang cemerlang, sebab dengan ide yang cemerlang dapat membantu kepala sekolah dalam peningkatan kinerja guru, dengan ide ini kepala sekolah dapat berkreasi dan berinovasi sehingga guru dapat bekerja secara maksimal, dengan optimalnya guru dalam bekerja, maka kegiatan belajar dan mengajar dapat berjalan secara baik, sehingga berdampak positif terhadap hasil belajar siswa. Hasil wawancara dengan kepala sekolah SMA Negeri 4 Kota Lubuklinggau adalah sebagai berikut:

"Saya selalu berpikir untuk mencari ide yang terbaik dalam peningkatan kinerja guru, dengan cara ini dapat mempermudah saya dalam membina guru di sekolah, guru-guru di sekolah masih banyak membutuhkan pembinaan terutama pembinaan mental, dengan pembinaan mental ini dapat memacu guru untuk bersemangat dan disiplin dalam bekerja"

Kreatifitas dan ide kepala sekolah sangat diharapkan dalam peningkatan kinerja guru, terutama dengan kemajuan teknologi yang serba canggih ini menuntut kompetensi guru dalam menguasai informasi dan teknologi, sehingga dengan mampunya guru menguasai dunia informasi dan teknologi sangat membantu guru dalam meningkatkan kinerjanya dalam proses belajar dan mengajar.

\section{Kiat Kepala Sekolah dalam Meningkatkan Kinerja Guru}

Kepala sekolah harus memiliki taktik dalam meningkatkan kinerja guru, terutama guru yang kurang dalam kinerjanya, seperti malas, kurang disiplin dan kurang kompetensinya, menghadapi guru yang demikian kepala sekolah harus 
memiliki taktik, agar guru yang bersangkutan benar-benar dapat bekerja secara optimal sesuai dengan apa yang diharapkan. Begitu juga guru yang kinerjanya bagus kepala sekolah juga harus mempunyai taktik dalam menghadapinya, sehingga kinerja guru yang sudah bagud ini dapat meningkatkan lagi kinerjanya menjadi lebih bagus. Hasil wawancara dengan kepala sekolah SMA Negeri 4 Kota Lubuklinggau adalah sebagai berikut:

"Taktik perlu diterapkan, apalagi menghadapi guru yang jumlahnya beragam dan memiliki kepribadian yang berbeda-beda, maka dari itu saya menggunakan taktik dalam menghadapi mereka, agar mereka mematuhi dan menuruti apa yang saya perintahkan"

Terkadang guru patuh dan taat di saat kepala sekolah ada di tempat, jikalau tidak, mereka masih bermalas-malasan dalam bekerja, hal demikian kurang mencerminikan peningkatan kinerja yang baik, maka dari itu taktik kepala sekolah sangat diharapkan dalam mengahadpi pola guru yang demikian, sehingga guru bekerja merupakan pengabdian profesinya sebagai guru, bukan bekerja dengan kepala sekolah, artinya ada kepala sekolah baru bekerja tidak ada kepala sekolah tidak mau bekerja. Hasil wawancara dengan salah seorang guru di SMA Negeri 4 Kota Lubuklinggau adalah sebagai berikut:

"Kami dulu seperti itu, namun dengan kepala sekolah yang ini kami termotivasi dan semangat dalam bekerja, karena kepala sekolah menggunakan pendekatan dan metode dalam menghadaapi persoalan guru, sehingga kami tidak sungkan untuk mengungkapkan permsalahan kami kepada guru”"

Disamping menggunakan taktik kepala sekolah menghadapi guru, kepala sekolah juga harus menggunakan langkah-langkah yang tepat dalam peningkatan kinerja, sebab dengan langkah-langkah yang jelas dapat memprmudah kepala sekolah dalam meningkatkan kinerja guru, artinya dimulai dari mana, apa yang perlu diselesaikan terlebih dahulu dan bagaimana mekanisme yang tepat dalam meningkatkan kinerja guru.

\section{Motivasi kepala sekolah dalam meningkatkan kinerja guru}

Dalam meningkatkan kinerja guru membutuhkan peran kepala sekolah. Peran kepala sekolah sangat penting sekali dalam meningkatkan kinerja guru karena kepala skolahlah yang mensupport dan memotivasi guru dalam bekerja dilingkungan sekolah disamping guru-guru yang lainnya. Terkadang kepala sekolah kurang respek dengan peningkatan kinerja guru, kepala sekolah bersifat acauh tak acuh mengenai peningkatan kinerja guru, sehingga jalinan komunikasi antara guru tidak ada sehingga terjadi kesenjangan antara guru dan kepala sekolah. Jikalau ini sering terjadi, maka akan sering terjadi miscomunication antara guru dan kepala sekolah, sehingga terjadi perdebatan dan akhrinya dimasing-masing pihak kurang respek terhadap tugas dan fungsinya masingg- 
masing. Hasil wawancara dengan kepala sekolah di SMA Negeri 4 Kota Lubuklinggau adalah sebagai berikut:

"Makanya saya selalu berniat didalam hati untuk bersunggug-sungguh dalam menjalankan amanah yang telah dibebankan kepada saya, maka dari itu saya berusaha semaksimal mungkin untuk menciptakan iklim organisasi yang sehat antara saya dengan guru-guru yang lainnya"

Menciptakan iklim organisasi yang baik adalah suatu keharusan dalam setiap organisasi, sebab dengan iklim yang sehat maka bawahan dalam hal ini guru dapat bekerja secara nyaman, dan rasa tanggungjawab dan memiliki sangat tinggi, hal ini terwujud apabila kepala sekolah bekerja secara sungguh-sungguh untuk meningkatkan kinerja guru. Guru tidak cukup hanya diberikan pembinaa, namun guru perlu kenyamanan dalam bekerja, sehingga guru merasa betah dan mencintai pekerjaannya. Hasil wawancara dengan guru di SMA Negeri 4 Kota Lubuklinggau adalah sebgai berikut:

"Ya kami sangat mendambakan kerjasama yang harmonis antara guru dengan kepala sekolah dan juga guru dengan guru, kerjasama yang harmonis diawali oleh kesungguhan kepala sekolah dalam menggunakan pendekatan dan komunikasi kepada guru sehingga guru dapat dengan mudah untuk mengeluarkan keluhan-keluhan mengenai urusan sekolah"

Minat kepala sekolah untuk meningkatkan kinerja guru sangatlah diharapkan, dengan minat yang kuat Insya Allah akan dapat dan tercapai apa yang diinginkan, minat harus tumbuh suburu dalam diri kepala sekolah dalam meningkatkan mutu sekolah terutama peningkatan kinerja guru, kepala sekolah hendaknya dapat mengorbankan waktu dan pikiran untuk peningkatan kinerja guru, dengan demikian rasa tanggungjawab kepala sekolah terhadap guru cukup tinggi, begitu juga guru dengan melihat rasa tanggungjawab kepapal sekolah terhadap guru cukup tinggi, maka guru diharapkan dapat memiliki rasa tanggungjawab yang tinggi pula dalam urusan sekolah.

\section{Faktor Pendukung dan Penghambat Peningkatan Kinerja Guru}

Dalam peningkatan kinera guru terdapat faktor penghambat dan pendukung, faktor penghambat diantaranya adalah ketersedian sarana dan prasarana sekolah, motivasi guru dan kompetensi guru, faktor penghambat ini jikalau tidak disikapi dengan baik dan cermat oleh kepala sekolah, maka peningkatan kinerja guru tidak akan tercapai dengan baik. Faktor penghambat jangan dijadikan penghalang dalam peningkatan kinerja guru, namun dijadikan kekuatan untuk selalu bersemangat dalam peningkatan kinerja guru. Hasil wawancara dengan kepala sekolah SMA Negeri 4 Kota Lubuklinggau adalah sebagai berikut:

"Ya, faktor penghambat dalam peningkatan kinerja guru sangat banyak sekali terutama keterpenuhan sarana dan prasarana sekolah, dalam hal ini 
ketersedian sarana dan prasarana sekolah, belum maksimal untuk mendukung peningkatan kinerja guru”

Ketersediana sarana dan prasarana merupakan faktor penting dalam peningkatan kinerja guru, dengan adanya sarana yang memadai akan lebih memotivasi guru dalam mengajar, seperti sarana media pembelajaran yang sangat membantu guru dalam menyampaikan materi pembelajaran, sarana media pembelajaran hendaknya dirancang dengan kraatif sehingga siswa tertarik dan termotivasi untuk belajar dan akan berdampak positif terhadap keberhasilan siswa. Hasil wawancara dengan guru SMA Negeri 4 Kota Lubuklinggau adalah sebagai berikut:

"Sarana media pembelajaran sangat membantu sekali bagi kami untuk mencapaikan materi pembelajaran kepada siswa, kami dengan mudah menyampaikan materi pembelajaran kepada siswa begitu juga siswa dapat dengan mudah menerima materi pembelajaran”

Keterpenuhan sarana dan prasarana dalam mendukung peningkatan kinerja guru sangatlah penting sekali, sebab guru akan termotivasi dan kreatif dalam menjalankan tugas pokok dan fungsinya, sarana yang baik akan menjamin kualitas pembelajaran yang baik, maka dari itu kepala sekolah harus berupaya secara maksimal untuk meningkatkan keterpenuhan sarana dan prasarana yang memadai dalam peningkatan kinerja guru. Hasil wawancara dengan kepala sekolah SMA Negeri 4 Kota Lubuklinggau adalah sebagai berikut:

"Ya saya berusaha secara maksimal untuk memenuhi keterpenuhan sarana dan prasarana sekolah, saya berusaha untuk menjalin kerjasama dengan pihak-pihak swasta dalam mendukung peningkatan kinerja guru begitu juga dengan masyarakat, sebab masyarakat juga ikut bertanggungjawab dalam kemajuan sekolah"

Disamping faktor penghambat dalam peningkatan kinerja guru terdapat juga faktor pendukung, sebab dengan adanya faktor pendukung dapat dijadikan modal yang sangat penting dalam peningkatan kinerja guru, faktor pendukung yang paling terbesar adalah keseriusan kepala sekolah dalam meningkatkan kinerja guru, sebab dengan adanya keseriusan kepala sekolah dapat menjadi modal besar dan paling berharga dalam peningkatan kinerja guru. Hasil wawancara dengan kepala sekolah SMA Negeri 4 Kota Lubuklinggau adalah sebagai berikut:

"Saya sangat komitmen sekali untuk meningkatkan kinerja guru, karena dengan meningkatnya kinerja guru dapat berdampak positif terhadap hasil belajar siswa, dengan meningkatnya hasil belajar siswa maka akan berdampak positif terhadap peningkatan mutu sekolah" 
Komitmen kepala sekolah dalam meningkatkan kinerja guru dapat dijadikan modal beharga bagi kepala sekolah untuk meningkatkan mutu sekolah, sebab kepala sekolah merupakan aktor kunci dalam peningkatan mutu sekolah, karena kepala sekolah memiliki kewenangan penuh terhadap keberhasilan sekolah. Maka dari itu komitmen dan keseriusan kepala sekolah sangat penting sekali dalam memajukan sekolah kedepannya.

\section{Pemahaman Kepala Sekolah dalam Meningkatkan Kinerja Guru}

Berdasarkan hasil wawancara di atas, bahwasanya kepala sekolah berusaha semaksimal mungkin untuk memahami kondisi dan suasana lingkungan sekolah dalam hal ini peningkatan kinerja guru, sehingga kepala sekolah dapat mengetahui kondisi dan keadaan guru dalam menjalankan tugas pokok dan fungsinya. Dengan demikian kepala sekolah telah melakukan salah satu tugas pokok dan fungsinya, yakni melakukan kegiatan kepengawasan dan kontrol terhadap kinerja guru. Sudarajat (2004) menjelaskan bahwa Tugas pokok dan fungsi kepala sekolah sebagai pemimpin pendidikan adalah: Perecanaan sekolah dalam arti menetapkan arah sekolah sebagai lembaga pendidikan dengan cara merumuskan visi, misi, tujuan dan strategi pencapaian; mengorganisasikan sekolah dalam arti membuat struktur organisasi, menetapkan staf dan menetapkan tugas dan fungsi masingmasing staf; Menggerakkan staf dalam artian memotivasi staf melalui internalmarketing dan memberi contoh eksternal marketing; Mengawasi dalam arti melakukan supervisi, mengendalikan dan membimbing semua staf dan warga sekolah; Mengevaluasi proses dan hasil pendidikan untuk dijadikan dasar pendidikan dan pertumbuhan kualitas; serta melakukan problem solving baik secara analitis sistematis maupun pemecahan masalah secara kreatif dan menghindarkan serta menanggulangi konflik.

\section{Kreativitas Kepala Sekolah dalam Meningkatkan Kinerja Guru}

Berdasarkan hasil wawancara di atas bahwasanya kreativitas kepala sekolah dapat meningkatkan kinerja guru lebih baik, kepala sekolah telah membangun tim kerja yang baik melakukan inovasi, melakukan kegiatan komunikasi terutama dalam peningkatan kinerja guru. Hal ini sesuai dengan pendapat Mulyasa (2005) menjelaskan bahwa kepala sekolah yang kretif dan profesional harus memperhatikan hal-hal sebagai berikut: Mempunyai visi atau daya pandang yang mendalam tentang mutu terpadu bagi lembaganya maupun bagi tenaga kependidikan dan peserta didik yang ada disekolah, mempunyai komitmen yang jelas pada program peningkatan kualitas, mengkomunikasikan pesan yang berkaitan dengan kualitas, menjamin kebutuhan peserta didik sebagai perhatian kegiatan dan kebijakan sekolah, menyakinkan terhadap para pelanggan pendidikan bahwa terhadap channel cocok untuk menyampaikan harapan dan keinginan, pemimpin mendukung pengembangan tenaga kependidikan, tidak menyalahkan pihak lain jika ada masalah yang muncul tanpa dilandasi bukti yang 
kuat, pemimpin melakukan inovasi, menjamin struktur organisasi yang menggambarkan tanggung jawabyang jelas, mengembangkan komitmen untuk mencoba menghilangkan setiappenghalang, baik bersifat organisasional maupun budaya, membangun tim kerja yang efektif dan mengembangkan mekanisme yang cocok untuk melakukan monitoringdan evaluasi

\section{Kiat Kepala Sekolah dalam Meningkatkan Kinerja Guru}

Kepala sekolah harus memiliki kiat khusus dalam meningkatkan kinerja guru sehingga kinerja guru dapat mengalami peningkatan secra signifikan dan dapat berdampak positif terhadap peningkatan hasil belajar siswa. Dalam Kamus Besar Bahasa Indonesia (1990) kiat adalah cara atau teknik, dalam hal ini cara atau teknik kepala sekolah dalam meningkatkan kinerja guru di SMA Negeri 4 Kota Lubuklinggau. Kepala sekolah SMA Negeri 4 Kota Lubuklinggau telah menerapkan kiat-kiat dalam meningkatkan kinerja guru diantaranya adalah melakukan pendekatan, dengan pendekatan perseuasif kepala sekolah dapat dengan mudah untuk meningkatkan kinerja guru. Pendekatan persuasif sangat efektif dalam meningkatkan kinerja guru, pendekatan ini mengedepankan lemahlembut dan sifatnya membina dan mengajak kearah yang lebih baik yakni peningkatan kinerja guru.

\section{Motivasi Kepala Sekolah dalam Meningkatkan Kinerja Guru}

Berdasarkan hasil wawancara di atas, bahwasanya kepala sekolah sangat bersungguh-sungguh dalam meningkatkan kinerja guru seperti menciptakan iklim organisasi yang baik dan melakukan komunikasi yang harmonis kepada bawahan dalam hal ini guru dan staf pegawai sekolah, dengan demikian kepala sekolah akan mampu memotivasi guru untuk dapat bekerja dengan lebih baik. Kepala sekolah harus memiliki motivasi yang kuat dalam meningkatkan kinerja guru, karena peningkatan kinerja guru merupakan tanggungjawab kepala sekolah, sebab dengan meingkatkanya kinerja guru, maka prestasi belajar siswa akan lebih baik, maka dari itu kepala sekolah hendaknya selalu termotuvasi terhadap peningkatan kinerja guru di sekolah. Moh Uzer Usman (1997) menjelaskan bahwa motivasi berasal dari kata motif yang merupakan daya dalam diri seseorang yang mendorongnya untuk melakukan sesuatu. Maka dapat didefenisikan bahwa motivasi adalah faktor-faktor yang timbul dalam diri kepala sekolah untuk meningkatkan kinerja guru di sekolah.

\section{Faktor Pendukung dan Penghambat Peningkatan Kinerja Guru}

Dalam melakukan suatu kegiatan tentunya memiliki faktor pendukung dan penghambat. Adapun faktor pendukung kepala sekolah dalam meningkatkan kinerja guru adalah keseriusan dan kesungguhan kepala sekolah dalam meningkatkan kinerja guru, sebab dengan adanya keseriusan kepala sekolah dapat menjadi modal besar dan paling berharga dalam peningkatan kinerja guru. 
Sedangkan faktor penghambat adalah ketersedian sarana dan prasarana sekolah yang kurang, motivasi guru dan kompetensi guru yang lemah, faktor penghambat ini jikalau tidak disikapi dengan baik dan cermat oleh kepala sekolah, maka peningkatan kinerja guru tidak akan tercapai dengan baik. Faktor penghambat jangan dijadikan penghalang dalam peningkatan kinerja guru, namun dijadikan kekuatan untuk selalu bersemangat dalam peningkatan kinerja guru.

\section{SIMPULAN}

Simpulan penelitian ini secara umum tentang strategi kepala sekolah dalam meningkatkan kinerja guru di SMA Negeri 4 Kota adalah kepala sekolah telah menerapkan strategi kepemimpinanya dengan baik, dengan cara memahami kondisi dan keadaan guru, kreatif dalam menerapkan gaya kepemimpinan, memiliki kiat-kiat dan memiliki motivasi yang tinggi untuk meningkatkan kinerja guru. Dengan memahami kondisi guru kepala sekolah akan mengetahui kondisi dan keadaan guru, kemudian juga kepala sekolah dapat menerapkan gaya kepemimpinan yang bervariatif, sehingga guru dapat menerima dan memahami kehendak kepala sekolah melalui gaya kepemimpinannya, kemudian kepala sekolah memiliki kiat-kiat dalam menghadapi guru sehingga kepala sekolah dapat membina dan memotivasi semangat guru dalam menjalankan tugas pokok dan fungsinya, dengan motivasi kepala sekolah yang tinggi dapat dijadikan modal yang paling berharga untuk meningkatkan mutu sekolah.

\section{DAFTAR PUSTAKA}

Ari, H. G. (1996). Administrasi Sekolah. Jakarta \: Rineka Cipta

Arikunto, A. (2002). Prosedur Penelitian. Bandung: Alphabeta

Balai Pustaka. (1990). Kamus Besar Bahasa Indonesia. Tim Penyusun Kamus BesarBahasa Indonesia. Departemen Pendidikan dan Kebudayaan. Pusat Pembinaandan Pengembangan Bahasa, Jakarta

Djamarah, D. (2000). Prestasi belajar dan Kompetensi Guru. Surabaya. Usaha Nasional

Mulyasa, M. (2005). Menjadi Guru yang Profesional. Bandung: Alphabeta

Reza, R. (2008). Strategi Belajar dan Mengajar. Jakarta: Gramedia

Sudrajat, H. (2004). Manajemen Peningkatan Mutu Berbasis Sekolah. Bandung: Alphabeta

Usman, U. (1997). Motivasi Mengajar Guru. Bandung: Alphabeta 